\title{
Full-length cDNA Cloning and Tissues Expression Analysis of Ferritin Gene from Acipenser sinensis
}

\author{
CHEN Xiao-wu, SHI Zhi-yi", CHENG Qian-qian \\ (College of Fisheries and Life Science, Shanghai Ocean University, Shanghai 201306, China)
}

\begin{abstract}
According to the conserved sequence of the ferritin gene, a homologous sequence was obtained from the EST database through a BLAST search against the GenBank database. This sequence was amplified with the method of RT-PCR, false sequencing was corrected, and full length cDNA of the ferritin subunit from the Chinese sturgeon was obtained. After being submitted to the GenBank database, the sequence accession number EU348782 was assigned. With the length of $896 \mathrm{bp}$, this cDNA includes entire coding regions of $531 \mathrm{bp}$, which encodes 176 amino acids (aa). The molecular weight was predicted to be $20339.9 \mathrm{Mr}$ and the theoretical isoelectric point 5.66 . It shares $82.9 \%$ protein sequence homology with the ferritin of the Atlantic salmon. This gene is expressed in many organs of the Chinese sturgeon, for example, the liver, pancreas, muscle, brain, heart and gastric mucosa. The highest expression level was found in the pancreas and the heart, while the muscular tissue showed the lowest. Homology modeling was used to predict the 3-D structure of the protein, which included 5 alpha helices and 10 turns. The ferritin protein structure could be overlapped and showed high similarity with that of human, frog and bacteria. It was revealed that this kind of ferritin was highly conserved in structure and function.
\end{abstract}

Key words: Acipenser sinensis; Ferritin; Bioinformatics

\section{中华鲟铁蛋白基因 cDNA 全长克隆与组织表达分析}

\author{
陈晓武，施志仪 ${ }^{*}$, 程千千 \\ （上海海洋大学 生物技术研究中心，上海 200090）
}

摘要: 根据铁蛋白基因的保守序列, 搜索 GenBank 数据库中华鲟的 EST 数据库得到一条同源序列。通过 RT-PCR 的方法对该序列进行扩增, 修改其测序错误, 获得中华鲟铁蛋白亚基 cDNA 全长, 经过注释提交 GenBank 数据库, 获取序列登录号 EU348782。该 cDNA 长度为 $896 \mathrm{bp}$, 包含 $531 \mathrm{bp}$ 的完整编码区, 推测编码的蛋白质为 $176 \mathrm{aa}$, 分 子量为 $20339.9 \mathrm{Mr}$, 理论等电点为 5.66。它和大西洋鲑鱼铁蛋白序列同源性最高, 达到 $82.9 \%$ 。该基因在中华鲟 肝脏、胰脏、肌肉、脑、心脏、鳃和胃粘膜等多种组织表达, 在胰脏和心脏中表达量较高, 在肌肉组织中表达较 低。根据同源模建的方法得到该蛋白质三维结构, 其包括 5 个 $\alpha$ 螺旋和 10 个转角结构, 和人、蛙和细菌的铁蛋白 均能很好的叠合，表现了很高的相似性，表明该蛋白结构和功能在基因进化中的高度保守性。

关键词: 中华鲟; 铁蛋白; 生物信息学

中图分类号: Q786 文献标识码：A 文章编号：0254-5853-(2009)02-0144-07

Belonging to the Osteichthyes, Acipenseriformes, Acipenseridae and Acipenser linnaeus, the Chinese sturgeon is mainly distributed through China where it is conserved under mandatory protection of first level. It holds an important position in the evolutionary system of fish, and furthermore, vertebrates. The lineage is known to be of significant age, and the species has been termed a "living fossil". Moreover, it also has significant economic value. Its caviar is referred to by some as "black gold". Recent increases in the Chinese aquaculture industry will certainly benfit from research on the digestion, physiology and the related genes of the Chinese sturgeon (Liu et al, 2006; Deng et al,1997).

Existing throughout the organism, ferritin is a protein with multiple subunits and multiple functions. It is an important protein for iron storage in cells. The

收稿日期：2008-09-23; 接受日期：2009-02-17

基金项目：上海市科学技术委员会重点科技攻关项目（073205109); 上海市重点学科建设项目（Y1101）

*通讯作者（Corresponding author）, 施志仪, Tel:021-61900051, E-mail: zyshi@shou.edu.cn

第一作者简介: 陈晓武 (1976-), 男, 讲师, 博士, 主要从事海洋生物学研究, Tel:021-61900437,E-mail: xwchen@shou.edu.cn 
ferritin stores excessive iron in the body, which helps avoid iron poisoning. It then supplies iron-requiring cells which synthesize the protein and enzyme in the body instead (Ferreira et al, 2000; Stites et al, 1999; Goto et al, 1999). Moreover, it can prevent excessive iron from producing active oxygen, therefore protecting the body from being harmed by oxidation (Balla et al, 1992). As the research object of the present study, the gene of ferritin of the Chinese sturgeon was cloned and analyzed. The related results will supply foundational material to understanding ferritin molecule evolution and its functions.

\section{Materials and Methods}

\subsection{Materials and reagents}

The tissue of the liver, pancreas, muscle, brain, heart and gastric mucosa were taken from a live juvenile Chinese sturgeon $(20 \mathrm{~cm})$ and stored in fluid nitrogen. The total RNA of all tissues was extracted by Trizol $^{\mathrm{R}}$ reagent (invitrogen) protocol and stored at temperature of $-80^{\circ} \mathrm{C}$. The clone plasmid pUCm-T, T4 ligase, $\mathrm{X}$-gal and IPTG were purchased from the Shanghai Shenergy Biocolour Co Ltd, the Spin Column DNA Gel Extraction Kit and the DNA electrophoresis marker from the Beijing Tiangen Biology Company, and the Realtime PCR Master Mix from the TaKaRa Biotechnology (Dalian) Co Ltd. Other reagents were all domestic analytically pure.

\subsection{Methods}

Using the mRNA sequence of ferritin from Atlantic salmon as the probe sequence, a BLAST search against the expressed sequence tags (ESTs) of the GenBank database was performed. This enabled a ferritin homology EST sequence of the Chinese sturgeon to be obtained. Amplification primers were designed according to this EST sequence. The amplification used primer sense (RT-Frritin-F: 5'-ATTTGGGTGACTTGCTTC-3') and primer antisense (RT-Frritin-R: 5'-GGTCCGCTTTGTTCTTAT-3'). The first chain synthesizing of the cDNA and the PCR conditions and systems were all done according to the manufacturer's instruction, with the annealing temperature at $53^{\circ} \mathrm{C}$ and PCR system $50 \mu \mathrm{L}$. After the PCR product was linked into pUCm-T plasmid, its sequencing was performed by the Shanghai Sangon Biology Project Co Ltd. Through analyzing and providing further information to the sequencing, one base sequence error in the original EST was corrected and the result was submitted to the GenBank database.
The real-time Q-PCR was used to analyze the expression of the ferritin gene. The process was as follows: the first chain of the cDNA reverse transcripted by the total RNA of 500ng was diluted with ten times of $1-10^{-4}$ as the template of the standard curve. The first chain of the cDNA reversed by the total RNA of $100 \mathrm{ng}$ was the sample template. The reaction was carried out with the Bio-Rad iCycler iQ (Bio-Rad, Hercules, CA, USA). The $20 \mu \mathrm{L}$ reaction system consisted of $10 \mu \mathrm{L}$ SYBR Premix Taq $^{\mathrm{TM}}(2 \times), 0.4 \mu \mathrm{L}$ forward primers $(10$ $\mu \mathrm{mol} / \mathrm{L}), 0.4 \mu \mathrm{L}$ reverse primers $(10 \mu \mathrm{mol})$ and the template of $1 \mu \mathrm{L}$. The reaction condition was $95^{\circ} \mathrm{C}, 15 \mathrm{~s}$, and the 45 cycles included the $95^{\circ} \mathrm{C}, 5 \mathrm{~s}, 58.9^{\circ} \mathrm{C}, 20 \mathrm{~s}$ and $72{ }^{\circ} \mathrm{C}, 15 \mathrm{~s}$. The fluorescence collection was performed after every cycle was over. There were 2 standard samples and 3 reference samples. The standard curve and the gene expression level was analyzed automatically by the system, as was the setting of the base line. The real-time Q-PCR of the $\beta$-actin and ferritin used primers $\beta$-actin-F (5'-ATGGTTGGTATGGGACAGAAAGA-3'), $\beta$-actin-R (5'-ATGGCTGGGGTGTTGAAGG-3'), Qferritin-S(5'-ACCTGTCGATGGCTCACTATTTC-3') and Qferritin-A (5'-CTCCTCCTCACTCTGCTCCTTG-3').

\subsection{Sequence analysis method}

Forty-two homologous sequences of ferritin from the osteichthyes were obtained from the databases of GenBank and SMART (Tab. 1) and all contained the FERRTIN protein domain. The ferritin structures of human (PDB database accession number: 1FHA), frog (PDB database accession number: 1MFR) and Escherichia coli (PDB database accession number: 1NFV) were all obtained from the PDB database (http://www.rcsb.org/pdb). The ferritin coding regions and domains were predicted online with ORFfinder (Wheeler et al, 2003) and SMART (Letunic et al, 2002). The SignalP 3.0 Server was used to predict the signal peptide (http://www.cbs.dtu.dk/services/SignalP/), the software Clustal $\mathrm{X}$ (version 1.83) to align the homologous protein sequences of the ferritin (Higgins et al, 1988; Chenna et al, 2003), and the software Phylip to construct the molecular phylogenetic tree according to the protein sequence (Felsenstein et al, 1989). Using the human ferritin structure as the template and the SWISS-MODEL long-distance server, the ferritin structure of the Chinese sturgeon was simulated (Schwede et al, 2003). The software PROCHECK for testing the structure and quality of the protein was used to evaluate the result of the homology modeling 
(Laskowski et al, 1993; Morris et al, 1992) and the Pymol to process the overlapping and comparison among the ferritin structures of the Chinese sturgeon, human, frog and E. coli.

Tab. 1 Sequence accession number, name, abbreviation and their homology with ferritin from Acipenser sinensis

\begin{tabular}{|c|c|c|}
\hline Accession number and species abbreviation & Ferritins and species & Protein homology $(\%)$ \\
\hline ABY81252.As & Ferritin, Acipenser sinensis & ID \\
\hline P49947.Ss & Ferritin, middle subunit [Salmo salar] & 82.9 \\
\hline P79822.Om & Ferritin H-2 [Oncorhynchus mykiss] & 82.3 \\
\hline ENSORLP00000020970.O1 & No description [Oryzias latipes] & 81.2 \\
\hline ENSGACP00000007893.Ga & No description [Gasterosteus aculeatus] & 81.2 \\
\hline Q4SBB8.Tn & Ferritin [Tetraodon nigroviridis] & 80.1 \\
\hline UPI000065E3A3.Tr & Middle subunit (Ferritin M). [Takifugu rubripes] & 78.2 \\
\hline Q6DHT8.Dr & Ferritin [Danio rerio] & 75.0 \\
\hline UPI0000F1DA3E.Dr & Hypothetical protein [Danio rerio] & 72.8 \\
\hline UPI00005459AF.Dr & Hypothetical protein [Danio rerio] & 72.8 \\
\hline UPI00005459A1.Dr & Hypothetical protein [Danio rerio] & 72.8 \\
\hline Q9DFP0.Gm & Ferritin middle subunit [Gillichthys mirabilis] & 72.3 \\
\hline P49946.Ss & Ferritin, heavy subunit [Salmo salar] & 71.7 \\
\hline UUI00005459AC.Dr & Hypothetical protein isoform 1 [Danio rerio] & 71.7 \\
\hline Q9DDT0.Dr & Ferritin heavy chain [Danio rerio] & 70.6 \\
\hline Q4JI28.Ip & Ferritin H-3 [Ictalurus punctatus] & 70.0 \\
\hline Q98TT0.On & Ferritin-H subunit [Oncorhynchus nerka] & 69.4 \\
\hline Q4JI31.Ip & Ferritin heavy subunit [Ictalurus punctatus] & 68.9 \\
\hline A6PYT7.Cr & Ferritin heavy chain [Chionodraco rastrospinosus] & 68.9 \\
\hline ENSGACP00000020432.Ga & No description [Gasterosteus aculeatus] & 68.3 \\
\hline ENSORLP00000007388.O1 & No description [Oryzias latipes] & 67.7 \\
\hline ENSORLP00000020968.O1 & No description [Oryzias latipes] & 67.6 \\
\hline Q4T4T6.Tn & Ferritin [Tetraodon nigroviridis] & 67.2 \\
\hline UPI000001914E.Tr & Eavy subunit (Ferritin H). [Takifugu rubripes] & 67.2 \\
\hline P02794.Hs & [Homo sapiens] & 66.6 \\
\hline ENSGACP00000020441.Ga & No description [Gasterosteus aculeatus] & 65.4 \\
\hline ENSORLP00000007742.O1 & No description [Oryzias latipes] & 61.3 \\
\hline Q7ZZT8.Om & Ferritin heavy subunit [Oreochromis mossambicus] & 60.2 \\
\hline UPI0000F20869.Dre & Hypothetical protein [Danio rerio] & 55.0 \\
\hline Q6Y241.Pm & Ferritin heavy chain [Pagrus major] & 53.4 \\
\hline Q9W6X5.O1 & Ferritin H3 [Oryzias latipes] & 52.2 \\
\hline Q2KKV5.Sc & Ferritin middle subunit [Siniperca chuatsi] & 52.2 \\
\hline Q3ZLF5.Om & Ferritin middle subunit [Oreochromis mossambicus] & 52.2 \\
\hline Q3ZLF4.Om & Ferritin lower subunit [Oreochromis mossambicus] & 50.5 \\
\hline Q2KKV6.Sc & Ferritin-H subunit [Siniperca chuatsi] & 50 \\
\hline ENSORLP00000008635.O1 & No description [Oryzias latipes] & 48.8 \\
\hline ENSGACP00000010650.Ga & No description [Gasterosteus aculeatus] & 48.3 \\
\hline UPI00002483B6.Dr & Hypothetical protein [Danio rerio] & 47.2 \\
\hline UPI0000365A30.Tr & Ferritin H subunit. [Takifugu rubripes] & 47.1 \\
\hline A0F008.Sm & Ferritin heavy chain [Scophthalmus maximus] & 45.4 \\
\hline UPI0000F1DA38.Dr & Hypothetical protein [Danio rerio] & 41.8 \\
\hline UPI0000F21A4F.Dr & Hypothetical protein [Danio rerio] & 33.5 \\
\hline UPI000056B0FA.Dr & Unknown [Danio rerio] & 26.5 \\
\hline UPI00005489B9.Dr & Similar to ferritoid [Danio rerio] & 22.7 \\
\hline
\end{tabular}

Species abbreviation: Acipenser sinensis(As); Oryzias latipes(Ol); Siniperca chuatsi(Sc); Danio rerio(Dr); Takifugu rubripes(Tr); Homo sapiens(Hs); Gasterosteus aculeatus(Ga); Chionodraco rastrospinosus(Cr); Ictalurus punctatus(Ip); Salmo salar(Ss); Pagrus major(Pm); Tetraodon nigroviridis(Tn); Gillichthys mirabilis(Gm); Oreochromis mossambicus(Om); Scophthalmus maximus(Am,); Oncorhynchus mykiss(Om); Ictalurus punctatus(Ip); Oncorhynchus nerka(On).

\section{Results}

\subsection{Full-length cDNA cloning and expression analysis of the ferritin gene}

To validate the assembled cDNA sequence, a
RT-PCR was conducted using primers flanking the ORF. When the extracted intestinal RNA sample was examined on a UV spectrometer, the readings was between 1.8-2.0 for $\mathrm{OD}_{260 / 280}$, and $>2.3$ for $\mathrm{OD}_{260 / 230}$, which indicates that the RNA had high purity and could be used for RT-PCR 
procedure. The PCR amplification was selected with the first chain of cDNA reversed by the total RNA of the liver, and the PCR product was about $800 \mathrm{bp}$ in size (Fig. $1)$.

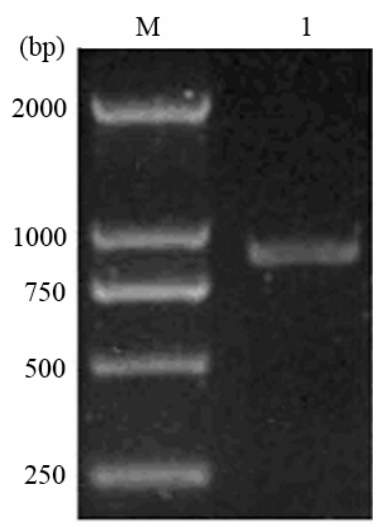

Fig. 1 Electrophoregram of RT-PCR products of ferritin expressed in liver

M.DNA Marker, 1. RT-PCR products

After the product was cloned and proved by the DNA sequencing, the rectified ferritin was submitted to GenBank (accession number EU348782). The coding region was predicted to be $531 \mathrm{bp}$, the initiation codon ATG and the termination codon TAA. A stop codon TGA and TAA are located upstream of the same reading frame, the cloned sequence has thus proven to be a full-length gene. The predicted protein had 176 amino acids (Fig. 2). The molecular weight of the protein was $20339.9 \mathrm{Mr}$ and the theoretical isoelectric point 5.66, without the signal peptide according to the prediction of the SignalP 3.0 Server. Besides, the numbers of the Leu and the Glu in this kind of protein sequence were 20 and 18 respectively, the former accounting for $11.4 \%$ of the total amino acid and the latter $10.2 \%$, with the highest molar percentage among the amino acids in the protein.

The result of the real-time Q-PCR indicated that this gene existed widely in many organs of the Chinese sturgeon, such as the liver, pancreas, muscle, brain, heart, gill and gastric mucosa, with the highest expression level in the pancreas and the heart and the lowest in the muscular tissue (Fig. 3).

\subsection{Gene sequence and protein structure of the ferritin}

There were nearly 2000 kinds of proteins determined to contain the ferritin protein domain by searching the SMART domain database (to March, 2008). They existed widely in the eukaryote (503 types), bacteria (1226types) and the archaebacteria (45 types),

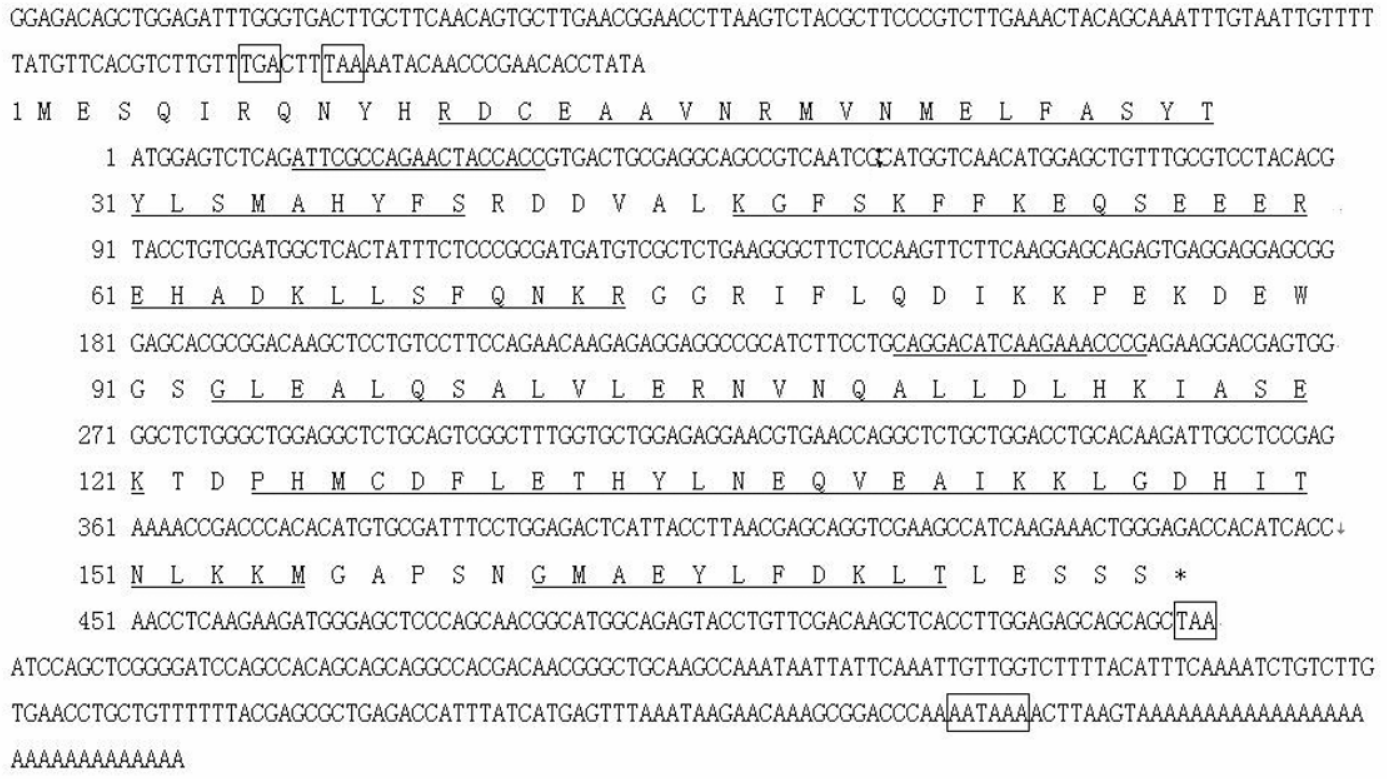

Fig. 2 Full-length cDNA and deduced amino acids sequence of ferritin from Acipenser sinensis Underlined amino acids are positions of HelixA (11-39), HelixB (46-71), HelixC (93-121), HelixD (124-155) and HelixE (161-171); Boxed TAA and TGA are terminal codons shared the same ORF with ferritin, the AATAAA is polyadenylation signal. 


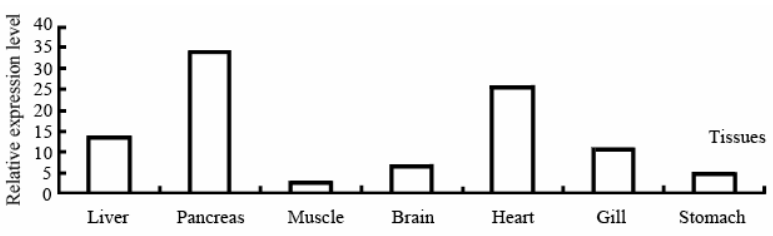

Fig. 3 Comparision of ferritin gene expression level in different organs of Acipenser sinensis

and there were still some without particular annotation. There are 44 kinds of ferritin of different fish in this study including the ferritin sequence of the Chinese sturgeon (Tab.1).

With the human ferritin light chain as the outgroup sequence, the molecular phylogenetic tree (Fig. 4) was constructed according to the ferritin protein sequences of the 44 kinds of fish. It showed the ferritin sequence of the Chinese sturgeon shared the highest homology with that of the trout $(82.9 \%)$, and the difference was relatively great compared with other homologous sequences with the lowest percentage of $22.7 \%$ (Tab.1). The ferritin of the fish already had differentiation in the ancient age, and the relatively ancient type was categorized as the type I, which contained 2 big classifications of II and III. The ferritin of the Chinese sturgeon was ancient in the type II, matching with the evolutional positions of other species, and the human ferritin light chain was in the type III. These facts revealed that the ferritin gene already had different subtypes of light chain and heavy chain in the early days and this gene could be a molecular index for the systematic evolution of the fish.

The ferritin sequence of the Chinese sturgeon was submitted to the SWISS-MODEL server. Through searching the PDB database with this program, a structure with $70.6 \%$ homology was obtained, and it was the human $\mathrm{H}$ chain ferritin (PDB accession number: 1FHA), which was in accordance with the condition of modeling. The neural network was selected for modeling and a structural model was obtained finally, including 5 alpha helices, 10 turns and 2 metal ion binding sites in the middle. This structure was then evaluated with the software PROCHECH, and the results were that the proportion of amino acid within the ramachandran plot was $94.3 \%$ (Fig. 5a), the dihedral angel 0.01 , covalent bond 0.44 and the angular distance 0.18 . It suggested that the simulated protein structure was relatively stable (Fig. $5 b$ ). Its structure had good superposition with that of the human $\mathrm{H}$ chain ferritin and E. coli ferritin, which showed although there were great changes in the sequence, the structure was still very conservative.

\section{Discussion}

The ferritin can collect and store the iron ion and be found in the cells of bacteria, plant and animal. It is a kind of ancient molecule, including two subtypes with different speeds of absorbing the ions: $\mathrm{H}$ type (also called $\mathrm{M}$ type) and L type. A big polymer is constituted by 24 subunits in the cells, the ratio between the $\mathrm{H}$ and $\mathrm{L}$ reflects the expression level of the two kinds of gene, and the expression is specific and can be influenced by the environmental factors as well (Theil et al, 1990). Experiments in vitro and in vivo show that iron absorbtion and storage can be influenced by changes in the structure of the ferritin polymer as well (Mertz et al, 1983). Therefore, cloning the ferritin gene is the foundation of exploring its function. Ferritin has copies in most human chromosomes, including the $\mathrm{X}$ chromosome. It is reported that the ferritin has the most subunits in the zebra fish, and it mainly distributes in the chromosome No. 3, 7 and 24. This research collected the protein containing the ferritin domain in fish that had been reported wheresome had been given detailed annotation, yet many had not. The homology between these sequences and that of the Chinese sturgeon was found to be great after they were aligned, with the highest greater than $82 \%$ and the lowest $22.7 \%$. The ferrintin subunit of the Chinese sturgeon had the highest homology with that of the M type of the Atlantic salmon and Japanese medaka (Oryxias latipes). Therefore, it belonged to the M type together with the type II in the phylogenetic tree in Fig. 4. But the type I in the same group with the human $\mathrm{L}$ chain ferritin belonged to the $\mathrm{L}$ type. Since the difference between the protein sequences and the result of the sequence alignment is found to be great, how does it maintain similar functions?

To explore the molecular characters of the ferritin of the Chinese sturgeon, this research simulated the 3-D structure of the ferritin according to the principle of homology modeling with the long-distance server SWISS-PROT. The general understanding of ferritin structure is always based on the human ferritin subunit (Lawson et al, 1991), frog ferritin (Ha et al, 1999) and the E. coli ferritin (Macedo et al, 2003). Research on the structure of fish ferritin is still unknown at present. With superposition and comparison, the ferritin structures of the human, frog and E. coli were found to be extremely similar in this paper. The result further revealed that although the primary structure difference of the ferritin 


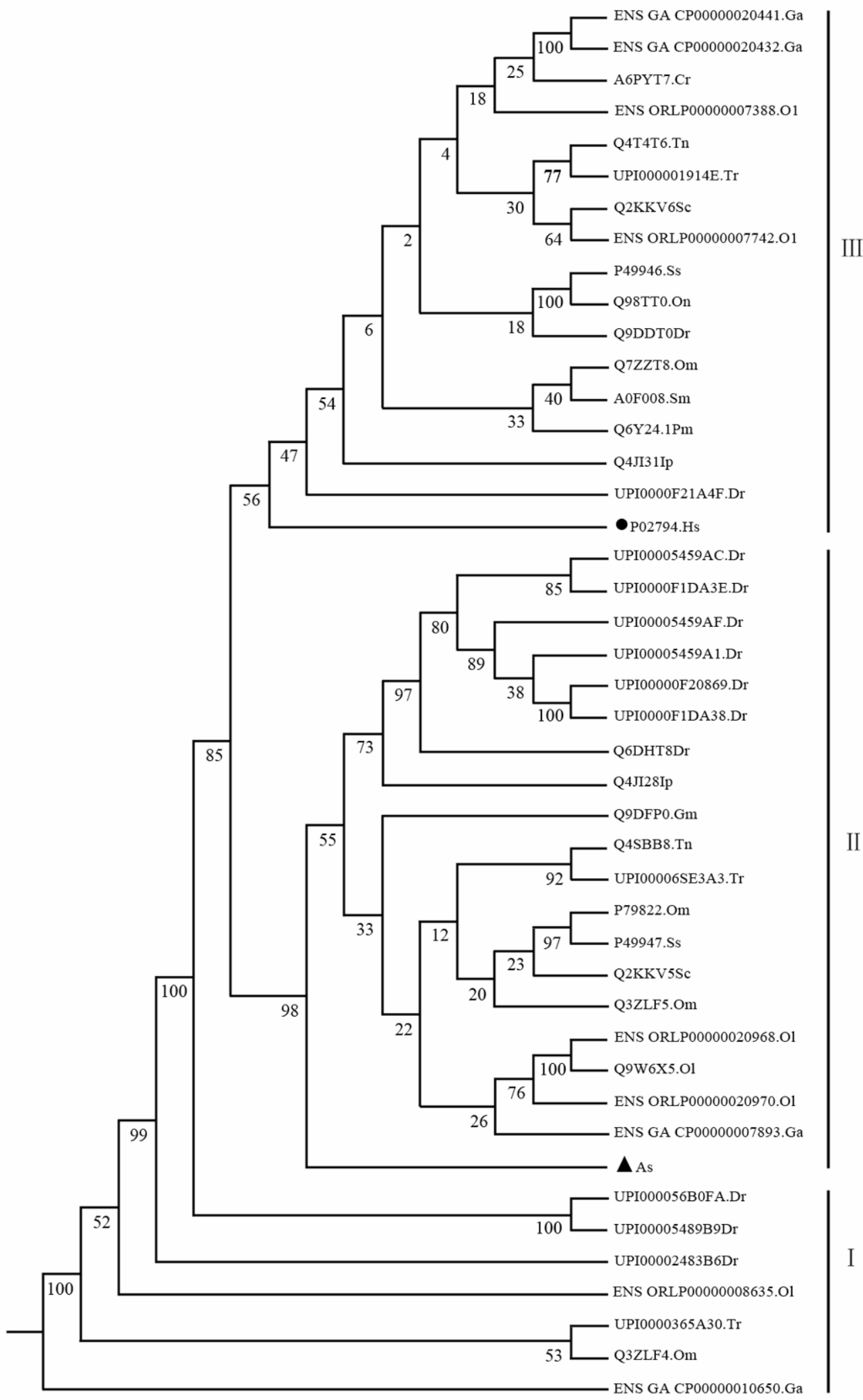

Fig. 4 Phylogenetic tree inferred from Ferritin amino acid sequences

The consensus tree was constructed by neighbor-joining bootstrap using PHYLIP3.63 software, bootstrap values were 100 trails. The solid black circle and triangle are used to emphasised the Ferritins from Homo sapiens and Acipenser sinensis. 


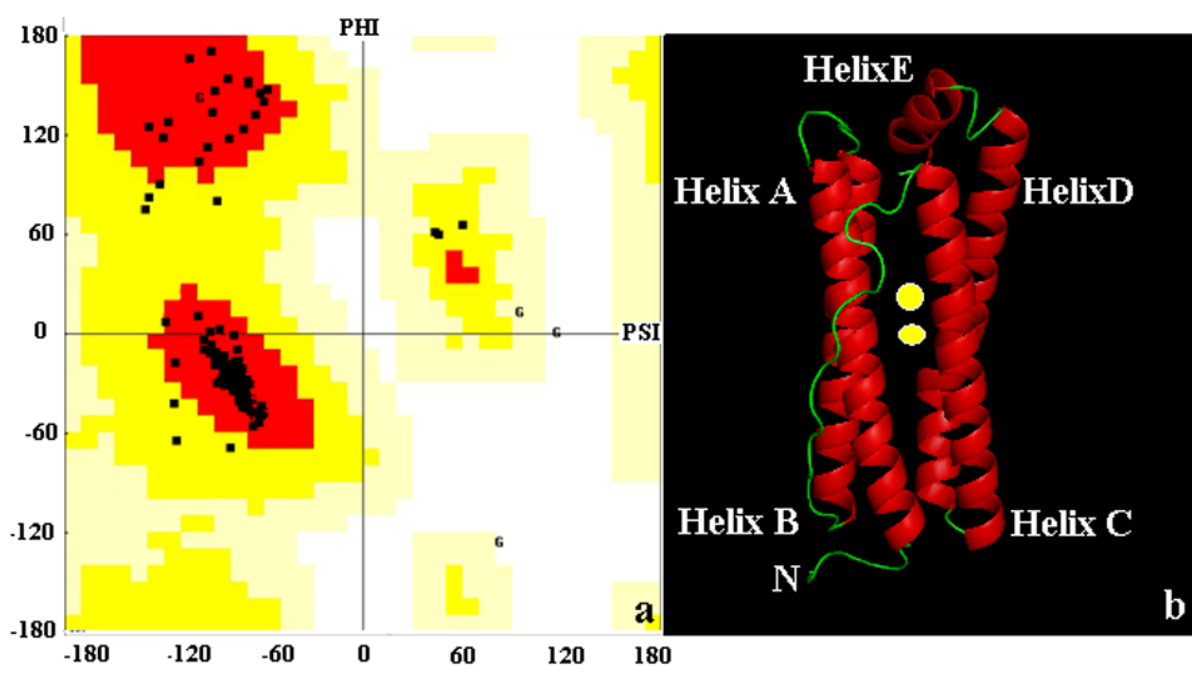

Fig. 5 The three dimensional model of ferritin subunit from Acipenser sinensis a: Amino acids in Ramachandran Plot; b: 3-D model of ferritin.

protein was great, different species still maintained stable tertiary structure which was the foundation of

\section{References:}

Balla G, Jacob HS, Balla J, Rosenbreg M, Nath K, Apple F, Eaton JW, Vercellotti GM. 1992. Ferritin: A cytoprotective antioxidant stratege of endothelium[J].Journal of Biological Chemistry, 267(25): 18148-18153.

Chenna R, Sugawara H, Koike T, Lopez R, Gibson TJ, Higgins DG, Thompson JD. 2003. Multiple sequence alignment with the Clustal series of programs[J]. Nucleic Acids Research, 31(13): 3497-3500.

Deng X, Deng ZL. 1997. Progress in the conservation biology of chinese sturgeon[J]. Zool Res, 18(1):113-120. (in Chinese)

Felsenstein J. 1989. PHYLIP-Phylogeny Inference Package (Version 3.2) [J]. Cladistics, 5: 164-166.

Ferreira F, Bucchini D, Martin ME, Levis S, Arosio P, Grandchamp B, Beaumont C. 2000. Early embryonic lethality of $\mathrm{H}$ ferritin gene deletion in mice[J]. J Biol Chem, 275(5): 3021-3024.

Goto F, Yoshihara T, Shigemoto N, Toki S, Takaiwa F. 1999. Iron fortification of rice seed by the soybean ferritin gene [J]. Nat Biotechnol Nature Biotechnology, 17: 282-286.

Ha Y, Shi D, Small W, Theil EC, Allewell NM. 1999. Crystal structure of bullfrog $\mathrm{M}$ ferritin at 2.8 A resolution: analysis of subunit interactions and the binuclear metal center[J]. Journal of Biological Inorganic Chemistry, 4(3): 243-256.

Higgins DG, Sharp PM. 1988. CLUSTAL: A package for performing

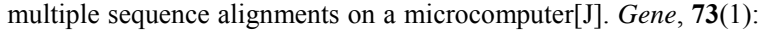
237-244.

Laskowski RA, MacArthur MW, Moss DS, Thornton JM. 1993. PROCHECK: A program to check the stereochemical quality of protein structures[J]. J Appl Cryst, 26: 283-191.

Lawson DM, Artymiuk PJ, Yewdall SJ, Smith JM, Livingstone JC, Treffry A, Luzzago A, Levi S, Arosio P, Cesareni G. 1991. Solving the structure of human $\mathrm{H}$ ferritin by genetically engineering intermolecular crystal contacts[J]. Nature, 349: 541-544. maintaining its similar functions in different organisms.

Letunic I. 2002. Recent improvements to the SMART domainbased sequence annotation resource[J]. Nucleic Acids Research, 30(1): 242-244.

Liu HB, Zhang Y, Yang YH, Ye JD, Sun DJ. 2006. Purification and partial characterization ofserum immunoglobulin in Acipenser sinensis, Acipenser schrenchii and Huso daurucus[J]. Journal of Fisheries of China, 30(4): 531-537.(in Chinese)

Macedo S, Romao CV, Mitchell E, Matias PM, Liu MY, Xavier AV, LeGall J, Teixeira M, Lindley P, Carrondo MA. 2003. The nature of the di-iron site in the bacterioferritin from Desulfovibrio desulfuricans[J]. Natural Structural Biology, 10(4): 285-290.

Mertz JR, Theil EC, Mertz JR, Theil EC. 1983. Subunit dimers in sheep spleen apoferritin: The effect on iron storage[J]. J Biol Chem, 258(19): 11719-11726.

Morris AL, MacArthur MW, Hutchinson EG, Thornton JM. 1992. Stereochemical quality of protein structure coordinates[J]. Proteins, 12(4): 345-364.

Schwede T, Kopp J, Guex N, Peitsch MC. 2003. SWISS-MODEL: an automated protein homology-modeling server[J]. Nucleic Acids Research, 31(13): 3381-3385.

Stites SW, Plautz MW, Bailey K, Brien-landner AR, Wesselius LJ. 1999. Increased concentrations of iron and isoferritins in the lower respiratory tract of patients with stable cystic fibrosis[J]. American Journal of Respiratory and Critical Care Medicine, 160(3): 796-801.

Theil EC. 1990. The ferritin family of iron storage proteins[J]. Adv Enzymol Relat Areas Mol Biol, 63:421-449.

Wsheeler DL, Church DM, Federhen S, Lash AE, Madden TL, Pontius JU, Schuler GD, Schriml LM, Sequeira E, Tatusova TA, Wagner L. 2003. Database resources of the National Center for Biotechnology Information[J]. Nucleic Acids Research, 31: 28-33. 